\title{
14-Türkçede terim oluşturma yolları ve bilişim terimlerinin oluşum süreçleri
}

\section{Ali Kemal ŞAŞı}

APA: Şaş, A. K. (2020). Türkçede terim oluşturma yolları ve bilişim terimlerinin oluşum süreçleri. RumeliDE Dil ve Edebiyat Araştırmaları Dergisi, (21), 242-256. DOI: 10.2900o/rumelide.843314.

\section{$\ddot{\mathbf{O} z}$}

Diller insanoğlunun geçirdiği bütün değişimleri en ince ayrıntısına kadar yansıtan mükemmel aynalardır. Her yeni buluş, eşya, fikir veya akım muhakkak dile akseder ve dilde temsil edilir. Bilimsel ve sanatsal alanlardaki ilerlemelerin yoğunluk kazanması insanın sözcüklerle olan ilişkisini de değiştirmiş; önceleri sadece nesne, durum ve olayları işaret etmek için kullanılan sözcükler zamanla zihinsel faaliyet ve ürünleri karşılamak için de kullanılır olmuştur. Böylece sadece belirli bir veya birkaç alanda kullanılan ve terim olarak adlandırılan özel kelimeler ortaya çımaya başlamıştır. Günümüzde teknolojik gelişmelerin çok yoğun bir şekilde yaşanması dilimizi de derinden etkilemiştir. Bu etkinin en fazla hissedildiği alanların başında söz varlığı gelmektedir. Zira yarım asır önce dilimizde bulunmayan pek çok sözcük ve terim artık sıklıkla kullanılmaya, dilimize yerleşmeye başlamıştır. Özellikle bilgisayar teknolojisinin müthiş bir hızla ilerlemesi ve bilgisayarların baş döndürücü bir hızla yaygınlaşması yüzlerce yeni bilişim teriminin günlük dile girmesine kapı aralamıştır. Çalışmanın birinci bölümünde bilişim teknolojilerinin ortaya çıkışı ve tarihî süreç içerisinde geçirdiği değişimlere değinildikten sonra bilgisayar teknolojisinin ülkemizdeki serüveni hakkında kısaca bilgi verilmiştir. İkinci bölümde terim kavramı tartışılmış, bir sözcük veya sözcük dizisinin terim olarak değerlendirilebilmesi için ne gibi özellikleri taşıması gerektiği üzerinde durulmuş ve bu özellikler maddeler hâlinde sıralanmıştır. Çalışmanın son bölümünde ise Türkçe terim üretme yolları tespit edilmiş, günümüz Türkçesinde kullanılan bilişim/bilgisayar terimlerinin oluşum süreçleri belirlenmiş ve söz konusu terimlerin hangi yöntemlerle oluşturulduğu istatistiki verilerle ortaya konmuştur.

Anahtar kelimeler: Terim, terimlerin özellikleri, terim yapma yolları, bilişim / bilgisayar terimleri

\section{The ways of forming terms in Turkish and the formation processes of informatics terms}

\begin{abstract}
Languages are perfect mirrors that reflect all the changes human beings go through to the finest detail. Every new discovery, item, idea or trend is definitely reflected and represented in language. The intensification of the advances in scientific and artistic fields has also changed the human relationship with words. In past the words were only used to indicate objects, situations and events but now words are used to achieve the purpose of mental activity and production over time. Thus, special words called terms began to emerge in one or more fields. Today, intense technological developments also deeply affected our language. Word presence is one of the areas where this effect is felt the most. Because many words and terms that were not found in our language half a century
\end{abstract}

Dr. Öğr. Üyesi, Kırșehir Ahi Evran Üniversitesi, Fen Edebiyat Fakültesi, Türk Dili ve Edebiyatı Bölümü (Kırșehir, Türkiye), kemalsas@ahievran.edu.tr, ORCID ID: 00oo-0001-6838-3018 [Araştırma makalesi, Makale kayıt tarihi: 19.11.2020-kabul tarihi: 20.12.2020; DOI: 10.29000/rumelide.843314]

Adres

İstanbul Medeniyet Üniversitesi, Eğitim Bilimleri Fakültesi, Türkçe ve Sosyal Bilimler Eğitimi Bölümü, Türkçe Eğitimi ABD Cevizli Kampüsü, Kartal-İstanbul/TÜRKIYY e-posta: editor@rumelide.com
Address

İstanbul Medeniyet University, Faculty of Education Sciences,

Turkish and Social Scinces Education, Turkish Language Teaching

Education, Cevizli Campus, Kartal-İstanbul /TURKEY

e-mail: editor@rumelide.com 


\begin{abstract}
ago are now frequently used and settled in our language. Especially, the rapid advancement of computer technology and the rapid spread of computers have opened the door for hundreds of new informatics terms to enter the daily language. In the first part of this study, after mentioning the emergence of information technologies and the changes it has undergone in the historical process, brief information is given about the adventure of computer technology in our country. In the second part, the term concept is discussed, In order for a word or a series of words to be evaluated as a term, it has been emphasized that what kind of characteristics must have and these characteristics are listed in items. In the last part of the study, the ways of generating Turkish terms are determined and emphasized on the formation processes of informatics / computer terms thast are used in today's Turkish language..
\end{abstract}

Keywords: Term, properties of terms, ways of making terms, informatics / computer terms

\title{
Giriş
}

İnsanoğlu, kendisinden ve en yakın çevresinden başlayarak evreni anlamaya ve adlandırmaya çalışmıştır. Çağlar boyunca devam eden bu çaba önceleri somut nesnelerin, sonrasında olayların ve soyut kavramların anlamlandırılıp isimlendirilmesiyle devam etmiştir. Hem çevresel hem de içsel zorunlulukların etkisiyle yiyecek, eşya ve bilgi üretmeye başlayan insanoğlu, bunların adlandırılmasında yeni bilgilerinin yanında eski bilgilerinden de faydalanmıştır. Ortaya koyduğu veya tanımladı̆̆ı yeni nesne, bilgi, kavram, olay ve olguları; çoğu zaman; önceden kullandığı sözcüklerde anlam, şekil veya ses değişikliği oluşturarak adlandırmıştır. Böylece her dilde eski ve yeni bilgiler arasında ilişki kuran, buna bağlı olarak da devamlı değişen ve gelişen sözcük hazineleri ortaya çıkmıştır.

Önceleri küçük gruplar hâlinde yaşayan insanoğlu, sonraları sosyalleşerek kalabalık topluluklar içerisinde var olmaya başlamıştır. Yaşadığı topluluğun büyüklüğüne koşut olarak ihtiyaçlarının artmasıyla tarımdan mimariye, gastronomiden el sanatlarına, ticaretten maliyeye, bürokrasiden hukuka, eğitimden iletişime kadar pek çok alanda yeni bilgiler oluşturmuştur. Zaman içerisinde, elde edilen bu bilgilerin saklanması, sınıflandırılması, iletilmesi gibi gereklilikler ortaya çıkmış, böylece bilişim teknolojileri ve ona bağlı olarak bilişim terminolojisi gelişmeye başlamıştır.

\section{Bilişim teknolojilerinin tarihî gelişimine kısa bir bakış}

"İnsanoğlunun teknik, ekonomik ve toplumsal alanlardaki iletişiminde kullandığı ve bilimin dayanağı olan bilginin özellikle elektronik makineler aracılı̆̆ıyla düzenli ve akla uygun bir biçimde işlenmesi bilimi" (www.tdk.gov.tr) şeklinde tanımlanan bilişimin tarihi oldukça eskiye dayanmaktadır. Tarım alanındaki gelişmeler neticesinde insanoğlu tüketebileceğinden daha fazla ürün elde etmeye başlamıştır. Zamanla elde edilen bu ürünlerin kaydının ve hesabının tutulması gerekmiş, bu iş için önceleri üzerlerine çentik atılan ahşap sopalar ve kilden yapılmış tabletler kullanılmıştır (Tameroğlu, 2001: 23). Ancak üretimin artmasıyla özellikle bürokrasi ve ticaret gibi alanlarda daha karmaşı işlemlerin yapılabileceği aletlere yani bilişim teknolojilerine ihtiyaç duyulmuştur.

Düzenli olarak vergi toplayan, geniş alanlardaki tarımsal ve ticari faaliyetleri yöneten, kalabalık halk kitlelerinin düzenini sağlayan devlet bürokrasisi hemen her dönemde bilişim teknolojilerine ilgi duymuştur. Bu teknolojiler tarih boyunca kamu idaresi, bilim ve ticaret alanında yoğun olarak kullanılmıştır (Taşçı ve Mutlu, 1991: 17-19). Ancak günümüzde bu durumun yeni bir boyuta evrildiği

\footnotetext{
Adres $\mid$ Address

İstanbul Medeniyet Üniversitesi, Eğitim Bilimleri Fakültesi, Türkçe İstanbul Medeniyet University, Faculty of Education Sciences, ve Sosyal Bilimler Eğitimi Bölümü, Türkçe Eğitimi ABD Cevizli Turkish and Social Scinces Education, Turkish Language Teaching Kampüsü, Kartal-İstanbul/TÜRKIYE $\quad$ Education, Cevizli Campus, Kartal-İstanbul /TURKEY e-posta: editor@rumelide.com 1 e-mail: editor@rumelide.com
} 
görülmektedir. Bilişim teknolojileri artık, tarih boyunca kullanılan temel alanların yanında başta savunma ve uzay sanayisi olmak üzere iletişim, eğitim, sağllk, mimari gibi pek çok alanda yoğun olarak kullanılmaktadır.

Pek çok araştırmacı, bilişim teknolojisinin ilk ürünü ve bugünkü bilgisayarların atası olarak M.Ö. 240o'lü yıllarda Çin'de kullanılmaya başlandı̆̆ı düşünülen abaküsleri göstermektedir. Bilinen en eski bilgi işlem aracı olan abaküsle en gelişmiş bilgi işleme aracı olan bilgisayar arasında hakiki bir soy ilişkisinin olduğu rahatlıkla söylenebilir (Taşçı ve Mutlu, 1991: 15).

Günümüzde baş döndürücü bir hızla ilerleyen bilişim teknolojilerinin tarih boyunca aynı hızla geliştiği söylenemez. Orta Çağ'da; Orta Doğu ve Kuzey Afrika'da sıfırın keşfi, ondalık sayı sisteminin kullanımı ve cebirin gelişmesi bilişim teknolojilerini desteklemiştir.

Avrupa'da 15. yüzyıldan itibaren nitelikli bilimsel araştırmaların yoğunluk kazanması, modern bilimin temellerinin atılmasını sağlamıştır. 17. yüzyılda büyük çarpma ve bölme işlemlerini pratik bir şekilde yapmayı sağlayan logaritma ile logaritmanın bir cetvel üzerine işlenmesi suretiyle oluşturulan hesap cetvelinin bulunuşu (Ellyard, 2017: 24) yoğun hesap gerektiren işleri oldukça kolaylaştırmıştır. Aynı dönemde geliştirilen Pascaline ve aritmometre adlı mekanik hesap aletleri modern hesap makinelerinin temelini oluşturmuştur.

Bilgisayara giden yoldaki en önemli adımlardan biri 19. yüzyılın başında atılmıştır. Fransız mucit Joseph Marie Jacquard, dokuma tezgâhında üretilen kumaşların üzerine pratik bir şekilde desen işlemeyi sağlayan delikli kartları icat etmiştir. Bu buluştan çok etkilenen Charles Babbage delikli kartlar vasıtasıyla denetlenen ve buhar enerjisiyle çalışan analitik makine isimli bir alet geliştirmiştir. (Aydoğdu vd., 2017; 4). Babbage'ın mali zorluklar sebebiyle tamamlayamadığı bu makine modern bilgisayarların ilham kaynağı olmuştur.

Amerikalı bilim adamı Herman Hollerith 19. yüzyılın sonlarına doğru depolanan bilgileri işleyebilen tabulator ve sorter adı cihazları geliştirmiştir. Böylece mekanik bilişim teknolojileri dönemi kapanmış, elektromekanik bilişim teknolojileri dönemi başlamıştır. (www.columbia.edu 2020; Taşçı ve Mutlu, 1991: 26).

20. yüzyılda bilişim teknolojilerinin gelişmesini sağlayan en önemli kişilerden biri Alman bilim adamı Cornard Zuse'tur. Zuse'un 1935 ile 1941 ylları arasında tasarladığı Z1, Z2, Z3 ve Z4 adlı cihazlar modern bilgisayarın ortaya çıkmasında çok önemli bir rol oynamıştır (www. history-computer.com 2020).

Modern bilgisayara yönelik ilk çalışmalar Avrupa'da yapılmış olsa da bilgisayar teknolojisinin asıl geliştirildiği yer Amerika Birleşik Devletleri'dir. John William Mauchly ve J. Presper Eckert'in 1946'da Amerika Birleşik Devletleri'nde geliştirdikleri Electronic Numerical Integrator and Computer (ENIAC) adlı sistem pek çok araştırmacı tarafından ilk bilgisayar olarak kabul edilmektedir (Campbell-Kelly vd. 2014: 71-72).

Külfetli kullanım prosedürleri ve çok pahalı olmaları sebebiyle bilgisayarlar 1970'li yılların ortalarına kadar çoğunlukla şirketler ve resmî kurumlar tarafından kullanılmıştır. Ancak bu durum 1976’da piyasaya sürülen Commodore ve 1984'te satışa sunulan Macintosh adlı bilgisayarlarla kalıcı olarak değişmiştir. Özellikle on ay gibi kısa bir sürede 2,000,00o adetlik satış rakamına ulaşan Macintosh

\footnotetext{
Adres $\mid$ Address

İstanbul Medeniyet Üniversitesi, Eğitim Bilimleri Fakültesi, Türkçe ve Sosyal Bilimler Eğitimi Bölümü, Türkçe Eğitimi ABD Cevizli $\quad$ Turkish and Social Scinces Education, Turkish Language Teaching Kampüsü, Kartal-İstanbul/TÜRKIYE $\quad$ Education, Cevizli Campus, Kartal-İstanbul /TURKEY e-posta: editor@rumelide.com $\mid$ e-mail: editor@rumelide.com
} 
(Taşçı ve Mutlu, 1991: 53) kişisel bilgisayarların yaygınlaşması ve geniş halk kitlelerinin bilgisayar teknolojisi ve terminolojisiyle tanışmasına büyük katkı sağlamıştır.

İnternetin yaygınlaşmasıyla bilişim teknolojilerinin cep telefonları, akıllı ev teknolojileri ve yeni nesil arabalar gibi sıradan insanların da sıklıkla faydalandığı çok farklı alanlarda yoğun olarak kullanılması bilişim terimlerinin günlük dilde çokça yer almasına zemin hazırlamıştır.

Dünyanın pek çok yerinde olduğu gibi Türkiye'de de bilişim teknolojileri ilk olarak devlet kurumları ve büyük şirketler tarafından denenmiştir. Mekanik ve yarı elektronik bilişim cihazları 1935'ten itibaren önce Devlet İstatistik Enstitüsünde (75. Yılında DİE, 2001: 165), sonraları Ziraat Bankası, Toprak Mahsulleri Ofisi, PTT, TCDD, Sümerbank gibi kurum ve kuruluşlarda yoğun bir şekilde kullanılmıştır.

Ülkemizde ilk bilgisayar 1960'da Karayolları Genel Müdürlüğü bünyesinde hizmete alınmıştır. Bu tarihten itibaren yurdumuzdaki pek çok kurum ve şirket bilgisayarlardan faydalanmıştır. Bilgisayarların yaygınlaşmasıyla bilgisayar terimlerinin Türkçeleştirilmesi ihtiyacı ortaya çımıştır. Bu amaca yönelik başta Türk Silahlı Kuvvetleri, Türk Dil Kurumu, Türkiye Bilişim Derneği, Türkiye Bilişim Vakfı, Türk Standartları Enstitüsü olmak üzere pek çok kurum, vakıf, dernek, üniversite ve bilim insanı Türkçe bilişim terimleri üzerine çalışmaya başlamıştır.

\section{Türkçe terim oluşturma yolları}

Bilimsel ve sanatsal alanlardaki ilerlemelerin yoğunluk kazanması insanın sözcüklerle olan ilişkisini de değiştirmiş; önceleri sadece nesne, durum ve olayları işaret etmek için kullanılan sözcükler zamanla zihinsel faaliyet ve ürünleri karşılamak için de kullanılır olmuştur. Böylece sadece belirli bir veya birkaç alanda kullanılan ve terim olarak adlandırılan özel kelimeler ortaya çıkmaya başlamıştır.

Terimler genellikle bilim, spor, sanat ve meslek alanlarına ait kavramları karşılayan; çoğunlukla o alan veya meslekle ilgili kişilerce kullanılan sözcüklerdir (Aksan, 2007: 40; Dilaçar, 1957: 207; Karaman, 2017: 93; Vardar, 2002: 197; Zülfikar, 1991: 1). Bu tanımdan da anlaşllacağı üzere sözcük veya söz öbeklerinin terim olarak değerlendirilebilmesi için bazı özellikleri taşıması gerekir². Bu özellikler şu şekilde sıralanabilir:

1. Terimler, yan ve mecaz anlamı olmayan tek anlamlı kelimelerdir.

2. Terimler yoruma kapalı; anlamı sınırlı, kesin ve açık olan kelimelerdir.

2 Terimlerin özellikleri için şu çalışmalara bakılabilir: Ahanov, K. (2013). Dil Bilimin Esasları. Ankara: TDK Yay., Aksan, D. (2007). Her Yönüyle Dil Ana Çizqileriyle Dilbilim. c. 3, Ankara: TDK Yay., Dilaçar, A. (1957). Terim Nedir? Türk Dili, C. 4, S. 64, s. 207-210., Cabré, T. M. (1999). Terminology: Theory, Methods and Applications. Amsterdam/Philadelphia: John Benjamins Publishing Company., Felber, H. (1984). Terminology Manual. Paris: UNESCO and Vienna: INFOTERM., Kahraman, M. (2017). Türk Dilinin Cumhuriyet Devri Terimsel Gelişim Sürecine Tarihî Bakış (II). İnsan ve Toplum Bilimleri Araştırmaları Dergisi, C. 6, S. 2, s. 1298-1312., Karaman, B. İ. (2009). Terim Oluşturma Yöntemleri. TDK Belleten, 2009-II., Karaman, B. İ. (2017). Terimbilimi. İstanbul: Bilgesu Yay., Özdem, R. H. (2000). Terimler Hakkında. Dilbilim Yazıları (Haz. Recep Toparlı). Ankara: TDK., Özdemir, E. (1973). Terim Hazırlama Kılavuzu. Ankara: TDK Yay., Özön, M. N. (1972). Terim Kılavuzu. İstanbul: Maarif Matbaası., Picht, H., Draskau, J. (1985). Terminology: An Introduction. The Copenhagen School of Economics. Guildford: University of Surrey., Rogers, M. A. (1997). Terminology. Department of Linguistic \& International Studies, School of Language \& International Studies, University of Surrey, Guildford, UK., Sager, J. C. (1990). A Practical Course in Terminology Processing. Amsterdam/ Philadelphia: John Benjamins Publishing Company., Sağlam, M. Y. (2006). Türkçedeki Terim Sorunsalı. Türkbilig, S. 14, s. 168-176., Sarıtosun, N. (1992). Terim Hazırlama Kılavuzu. İstanbul: İ.T.Ü. Yay., Şahin, H. (2006). Terimlerin Genel Dile Yansımasına Dair Bazı Gözlemler. Sosyal Bilimler Enstitüsü Dergisi, Bursa, 2006 / 1, s. 123-129., Suonuuti, H. (1997). Guide to Terminology. Nordterm Series. Helsinki: Tekniikan Sanastokeskus ry., Tariktaroğlu, A. (1998). Türk Dilinde Terimler. Türk Dili, S. 559, s. 74-80., Uysal, H. (2013). Yabancı Terimleri Türkçeleştirmede Uygulanan Yöntem ve İlkeler (1932-1950 arası). (Yayımlanmamış Yüksek Lisans Tezi) Ankara, Ankara Üniversitesi S.B.E., Vardar, B. (1980). Terimsel Etkinlik ve Terimbilim. Türk Dili, (XLI/46), s. 385-389. Zülfikar, H. (1991). Terim Sorunlart ve Terim Yapma Yolları. Ankara: TDK Yay.

Adres

İstanbul Medeniyet Üniversitesi, Eğitim Bilimleri Fakültesi, Türkce ve Sosyal Bilimler Eğitimi Bölümü, Türkce Eğitimi ABD Cevizli Kampüsü, Kartal-İstanbul/TÜRKIYE e-posta: editor@rumelide.com
Address

İstanbul Medeniyet University, Faculty of Education Sciences,

Turkish and Social Scinces Education, Turkish Language Teaching

Education, Cevizli Campus, Kartal-İstanbul /TURKEY

e-mail: editor@rumelide.com 
3. Terimler kullanıma bağlı olarak anlam kayması veya genişlemesine uğramaz.

4. Terimler genel dilde yer almaz ancak genel dilden seçilip terimleştirilmiş sözcükler vardır.

5. Genel dilden seçilip terimleştirilen sözlerin, terim anlamı dışında kalan bütün anlamları silinir.

6. Terimler, dilin doğal seyri içerisinde oluşmaz; çoğu zaman alanın uzmanı olan kişilerce oluşturulur.

7. Terimler, ifade ettikleri kavramlar genelleşip günlük dilde yaygın olarak kullanıldıklarında, terim olma özelliklerini kaybeder. Ancak bu sözcükler ait oldukları bilim, spor, sanat ve meslek alanında terim olma özelliklerini korur.

8. Terimler bağımsız biçim birimleridir.

9. Terimlerin dil içerisindeki dolaşımları ait oldukları bilim, spor, sanat ve meslek alanındaki kişilerin dilinde gerçekleşir.

10. Terimlerin çok önemli bir bölümü belirli bir alana aitken küçük bir bölümü, aynı anda farklı sahalarda kullanılabilmektedir.

11. Terimler ses, şekil, anlam ve kullanım yönünden ölçünlü sözcüklerdir.

Diller, toplumların geçirdikleri sosyokültürel değişimlerin en bariz şekilde gözlemlendiği alanların başında gelir. Türklerin 10. yüzyıldan itibaren İslamlaşması Türk dilini de derinden etkilemiş, Arapça pek çok kelime ve kaidenin Türkçeye kopyalanmasına zemin hazırlamıştır. Başlangıçta dinle ilgili sözcükler kopyalanırken zamanla edebiyattan tıbba kadar pek çok alandaki sözcüklerin doğrudan veya dolaylı olarak Türkçeye aktarıldığı gözlemlenmiştir. İslam medeniyetinde bilim dili olarak Arapçanın benimsenmesi Türkçe eserlerde Arapça terimlerin sıklıkla kullanılması sonucunu ortaya çıkarmıştır. Bu durum 16. yüzyıldan sonra kendini kesif bir şekilde hissettirmiş, netice itibarıyla pek çok sahadaki terminoloji Arapça sözcüklerle oluşmuştur.

18. yüzyılın son çeyreğinden itibaren büyük bir ivme kazanan ıslahat hareketleri Batılı devletlerle sıkı ilişkiler kurmamızı sağlamıştır. Bu ilişkiler neticesinde Osmanlı Devleti’nin idari ve siyasi yapısı Avrupa ülkelerindekilere benzer şekilde yeniden oluşturulmuştur (Kara, 2016: 24; Levend, 2010: 102112). Bu değişim rüzgârı eğitim alanında da etkili olmuş ve Batıdaki örneklere benzer pek çok yeni okul açlmıştır. Yeni bir anlayışla ihdas edilen kurum ve okullar faaliyete geçtikleri andan itibaren terminoloji sorunlarıyla karşı karşıya gelmişlerdir. Dönemin devlet adamları ve aydınları bu sorunu aşabilmek için Batıdan gelen terimlere, genellikle Arapça ve Farsça unsurlarla karşllı üretme yoluna gitmiştir (İhsanoğlu, 1985: 85). Pek çok dilde ortak olan ve artık uluslararası bir kimlik kazandığı düşünülen terimler ise olduğu gibi kabul edilmiştir (Eker, 2013: 69-71).

Cumhuriyet Dönemi'nde, pek çok alanda olduğu gibi terim üretme konusunda da kararlı adımlar atılmış, yabancı dillerde üretilen terimleri Türkçe sözcüklerle karşılama anlayışı benimsenmiştir. Terimlerin Türkçeleştirilmesini içeren ilk resmî teklif 1923'te Tunalı Hilmi tarafindan Meclise sunulmuş ancak şartların uygun olmaması sebebiyle önemli bir etki oluşturmamıştır (Levend, 2010: 391).

12 Temmuz 1932'de Türk Dili Tetkik Cemiyetinin kurulmasıyla Türk dili alanındaki çalışmalar hızlanmış, 26 Eylül - 4 Ekim 1933 tarihlerinde toplanan I. Türk Dili Kurultayı'nda Türkçe istılah (terim) lügatinin oluşturulması kararlaştırılmıştır (Levend, 2010: 415; Özdemir, 1980: 50). Bu kurultaydan sonra on altı alanda terim komisyonları oluşturulmuş ve terimlerin Türkçeleştirilme çabaları hız kazanmıştır. Başlangıçta ilk ve ortaöğretim ders kitaplarındaki terimlerin Türkçeleştirilmesi üzerinde durulmuş ve bu alanda büyük mesafe katedilmiştir. 1950'lerden itibaren ise yükseköğretime yönelik ders kitaplarındaki terimlerin Türkçeleştirilmesine hız verilmiştir. Türk Dil

\footnotetext{
\begin{tabular}{r|l} 
Adres & Address \\
İstanbul Medeniyet Üniversitesi, Eğitim Bilimleri Fakültesi, Türkçe & İstanbul Medeniyet University, Faculty of Education Sciences,
\end{tabular} ve Sosyal Bilimler Eğitimi Bölümü, Türkce Eğitimi ABD Cevizli $\quad$ Turkish and Social Scinces Education, Turkish Language Teaching Kampüsü, Kartal-İstanbul/TÜRKIYY $\quad$ Education, Cevizli Campus, Kartal-İstanbul /TURKEY e-posta: editor@rumelide.com 1 e-mail: editor@rumelide.com
} 
Kurumu yönetici ve çalışanları Türkçe terim sözlüklerinin hazırlanması konusunda büyük çaba göstermiş, 2010’a kadar 110 civarında terim sözlüğü ve karşıllklar kılavuzu yayımlanmıştır (Eker, 2013: 75; Köksal, 1983: 270).

Cumhuriyet Dönemi’nde farklı bilim ve sanat dallarına ait pek çok terim sözlüğü ve karşlıklar kılavuzu düzenlenmesine karşın terimlerle ilgili kuramsal çalışmalara pek önem verilmemiş, terim üretme yollarını işleyen sınırlı sayıda monografik eser kaleme alınmıştır. Ragıp Hulusi Özdem'in 1941'de hazırladığı Terim Meselesi Münasebetiyle Dilimizin Islahı Üzerinde Bir Muhtıra, M. N. Özön'ün 1972'de tamamladığ Terim Kılavuzu, Emin Özdemir’in 1973'te yayımladığı Terim Hazırlama Kılavuzu, Hamza Zülfikar'ın 1991'de kaleme aldı̆̆ı Terim Sorunları ve Terim Yapma Yolları, Nadiye Sarıtosun'un 1992'de telif ettiği Terim Hazırlama Kılavuzu, Burcu İlkay Karaman'ın 2009'da yayımladı̆̆ı Terim Oluşturma Yöntemleri adlı makalesiyle 2017'de hazırladığı Terimbilimi gibi eserlerin yanında Hülya Uysal'ın 2013'te tamamladığı Yabancı Terimleri Türkçeleştirmede Uygulanan Yöntem ve İlkeler (1932-1950 arası) adlı yüksek lisans tezi Türkçe terim yapma yollarını doğrudan ele alıp inceleyen eserlerdir. Ayrıca Sertan Alibekiroğlu, Türkçede Sözcük Yapımı adlı eserinin bir bölümünü terim yapımına ayırmıştır.

Her çağda terimlere ihtiyaç duyulmuş ve terim sorunuyla karşılaşılmıştır. Ancak içinde bulunduğumuz çağda tarihin hiçbir döneminde görülmemiş, çok büyük bilimsel ilerlemeler olmuş ve pek çok alanda yeni adlandırmaları gerektirecek buluşlara imza atılmıştır. Bu durum yeni terim ihtiyacını had safhaya çıkarmış, buna paralel olarak terim yapma faaliyetleri hız kazanmıştır. Terim yapımı pek çok alanı ilgilendiren çok katmanlı bir süreçtir. Terimin ait olduğu alanın yanında dilsel ve sosyokültürel disiplinlerin de etkisi altındadır. Sözlük biliminin yanında şekil bilgisi, söz dizimi ve anlam bilgisi gibi alanların yeni terimlerin oluşumunda önemli katkıları vardır. Diğer taraftan kültürel değişimler, toplumsal yönelimler ve diller arası ilişkiler de terimleşme sürecine doğrudan etki etmektedir.

Terimler diğer dil göstergelerinin aksine dilin tabii seyri içerisinde oluşmaz. Herhangi bir alanda bir terimin oluşabilmesi için belirleme, çözümleme, yaratım ve ölçünleme gibi aşamaların geçilmesi gerekir (Vardar, 1980: 387). Bu ilkelerden ve bugüne kadar ortaya konan bilimsel çalışmalardan hareketle Türkçe terim oluşturma yöntemleri şu başlıklar altında toplanabilir:

1. Türetme (derivation),

2. Örnekseme (analogy),

Ana dilden örnekseme

Yabancı dilden örnekseme

3. Tür değiştirme (conversion),

4. Genel dilden sözcük aktarma3 ${ }^{3}$,

5. Ağızlardan sözcük aktarma,

6. Tarihî lehçelerden sözcük aktarma,

7. Çağdaş lehçelerden sözcük aktarma,

8. Birleştirme (compounding),

9. Kurpma (clipping),

\footnotetext{
3 Genel dilden seçilen bir sözcüğ̈̈n herhangi bir alanda terim olarak kullanılmasıdır. Bu yöntem için Özdemir (1973: 28) ve Sarıtosun (1992: 19) anlam aktarımı karşılı̆̆ını kullanmıştır. Karaman (2017: 114) ise bu yöntemi çokanlamlllk (benzetme, eğretileme, düzdeğişmece, eşadlılık) başlı̆̆ altına incelemiştir. 


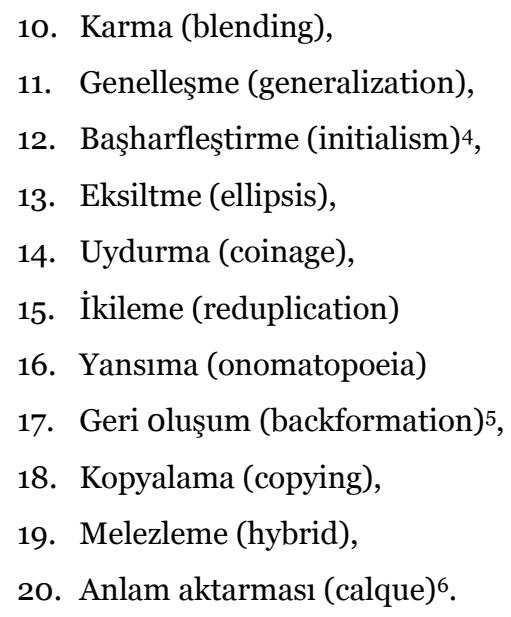

\section{Türkçe bilişim terimlerinin oluşum süreçleri}

Terimler ilk olarak bilim, sanat, felsefe ve spor gibi alanlarda ilerleyen milletlerin dillerinde görülür. Her ne kadar bilgisayar üzerine ilk çalışmalar Avrupa'da yapılmışsa da bilgisayarın geliştirildiği ve üretildiği asıl yer Amerika Birleşik Devletleri'dir. O sebeple bilgisayarlarla ilgili bütün terimler ilkin İngilizce olarak üretilmiştir (Köksal, 1981: 10). Uzunca bir süre sadece Türkçe değil dünya dillerinin tamamı bilişim terimleri hususunda İngilizcenin etkisi altında kalmıştır. Zamanla bu durum değişmeye başlamış ve pek çok millet, İngilizce bilişim terimlerine kendi dillerinde karşlıklar üretme yoluna gitmiştir.

Ülkemizde bilişim terimleri ilk bilgisayarın Türkiye’ye geldiği tarih olan 1960'tan itibaren sıklıkla kullanılmaya başlamıştır. Terimlerin Türkçeleştirilmesi konusunda Tanzimat’tan beri süren tartışma bilişim terimleri alanında da kendini göstermiş, pek çok kişi dünyadaki gelişmelerden kopacağımız ve bilgisayarın ancak İngilizce konuşarak kullanılabileceği gibi gerekçelerle bilişim terimlerinin Türkçeleştirilmesine karşı çıkmıştır. Ancak bu anlayış zaman içerisinde terk edilmiş ve bilişim terimlerini Türkçeleştirme çalışmaları başlamıştır.

Bilişim terimlerinin Türkçeleştirilmesine dair ilk önemli çalışma Türk Silahlı Kuvvetleri bünyesinde yapılmıştır. Dr. Müh. Tğm. Okan Gürel ve Y. Müh. Tğm. Olcay Göksu'nun 1964’te hazırladıkları

4 Çok sözcüklü isimlendirmelerde sadece baş harfleri alarak sözcük oluşturmadır. Ancak bazı durumlarda harflerin yanında kelime parçaları da kısaltılabilmektedir.

Dilde yaşayan bir sözcük veya tabandan belirli bir bölümü çıarmak suretiyle dilde o zamana kadar bulunmamıs daha küçük bir sözcük oluşturmadır. Bu yöntem için Eker (2003: 329) ters türetme, Demirci (2017: 165) ise geri türetme karşıllı̆̆ını kullanmıştır.

6 Farklı kaynaklarda muhteva iktibası, ödünçlemeli çeviri, çeviri sözcük, anlam etkilenmesi, anlam kopyalaması, öykünme, öyküntü, kalka, kalque gibi terimlerle karşllanan anlam aktarması; kaynak dildeki bir ibarenin hedef dile bire bir aktarılması (Vinay ve Darbelnet, 1995: 31) șeklinde tanımlanabilir. Yani bu yöntemde yabancı söz veya yapılara bakılarak oluşturulan ancak ait oldukları dilin kendi ögelerinden elde edilen sözcük ve şekiller söz konusudur. Ayrıntılı bilgi için şu çalışmalara bakılabilir: Aksan, D. (1961). Anlam Alışverişi Olayları ve Türkçe. TDAY Belleten, s. 167-184. Buran, A. (2006). Dil İlişkileri ve Kavram Tercümeleri Üzerine Bỉr Değerlendirme. 12. Uluslararası KIBATEK Edebiyat Şöleni, Bakü/Azerbaycan: 10-17 Mayıs: s. 1-4, Günay, D. (2007). Sözcükbilime Giriş. İstanbul: Multilingual Yay., Haugen, E. (1950). The analysis of linguistic borrowing. Language, 26, 210-231. İmer, K. (2001). Türkiye'de Dil Planlaması: Türk Dil Devrimi. Kültür Bakanlığı Yay., Johanson, L. (2018). Türkçe Dil İlişkilerinde Yapısal Etkenler (Çev. Nurettin Demir). Ankara: TDK Yay., Karaağaç, G. (1997). Alıntı Sözcükler Üzerine Düşünceler. Türk Dili. S. 552, s. 499-511., Önen, Y. (1955). Alman Dilindeki Muhteva İktibasları Üzerine Araştırmalar. Ankara Üniversitesi Dil ve TarihCoğrafya Fakültesi Dergisi, 13(4), 13-38., Sarı, İ.. (2015). Türkçede Ekleme Dışı Sözcük Yapımı ve Sözlükselleşme. Yayımlanmamış Doktora Tezi, Ankara: Hacettepe Üniversitesi Sosyal Bilimler Enstitüsü, Uysal, H. (2013). İlk Dönem Türkçeleştirme Çalışmalarında (1932-1950) Öyküntü Yöntemi (Calque) ve örnekleri. A. Ü. DTCF Türkoloji Dergisi, C. 2,S. 20, s. 111-134. Vinay, J.P., Darbelnet, J. (1995). Comparative Stylistics of French and English: A Methodology for Translation. Joh Benjamins Publishing.

Adres

İstanbul Medeniyet Üniversitesi, Eğitim Bilimleri Fakültesi, Türkçe ve Sosyal Bilimler Eğitimi Bölümü, Türkçe Eğitimi ABD Cevizli Kampüsü, Kartal-İstanbul/TÜRKIYE e-posta: editor@rumelide.com
Address

İstanbul Medeniyet University, Faculty of Education Sciences,

Turkish and Social Scinces Education, Turkish Language Teaching

Education, Cevizli Campus, Kartal-İstanbul /TURKEY

e-mail: editor@rumelide.com 
Otomatik Bilgi İşlem Terimleri adlı eser, ilk Türkçe bilişim terimleri sözlüğüdür. İçerisinde 650 civarında terimi barındıran eser iki ana bölümden oluşmaktadır. Birinci bölümde Türkçe terimlerin İngilizce karşlıkları verilmiş, ikinci bölümde ise İngilizce ve Türkçe terimlerin açılamaları yapılmıştır. Aynı yıl Şenol Utku tarafından Türkçeye tercüme edilen IBM 1620 Fortran II Spesifikasyonları adlı eserin içerisinde 121 adet Türkçe bilişim terimi İngilizce karşıllklarıyla birlikte listelenmiştir.

Hacettepe Üniversitesinde 1967 yllında Bilgi İşlem Merkezinin, 1977'de ise Bilgisayar Mühendisliği Bölümünün açılması bilişim terimlerinin eğitim alanında kullanılmasını sağlamıştır. Sonrasında pek çok üniversitede bilgisayara yönelik ve bilgisayar vasıtasıyla eğitim veren bölümlerin açılması bilişim terimlerinin Türkçeleştirilmesi yönündeki çabaları hızlandırmıştır.

Devlet kurumları ve üniversitelerin yanında çeşitli sivil toplum kuruluşları da bilişim terimlerinin Türkçeleştirilmesine katkıda bulunmuştur. Bu kuruluşlardan 1971'de Aydın Köksal'ın önderliğinde faaliyet göstermeye başlayan Türkiye Bilişim Derneği (TBD) bilişim dilinin Türkçeleştirilmesi adına önemli çalışmalara imza atmıştır. Söz konusu derneğin bünyesinde 1978 'de Bilişim Terimleri ve Öneriler Kılavuzu, 1996'da ise Bilişim Terimleri Sözlüğü adlı iki önemli eser hazırlanmıştır. Diğer taraftan dernek içerisinde oluşturulmuş Türk Dünyası Ortak Bilişim Terimleri Çalışma Grubu ve Bilişimde Özenli Türkçe Çalışma Grubu hem bilişim dilinin yabancı unsurlardan temizlenmesi hem de Türk dünyasında ortak bir bilişim terminolojisinin oluşması için çaba göstermektedir. Türkiye Bilişim Derneğinin yayın organı olan Bilişim dergisi ile Elektrik Mühendisliği, Türk Dili ve Varlık Yıllı̆̆ı gibi dergilerinde bilişim literatürünün Türkçeleştirilmesine yönelik pek çok çalışma yayımlanmıştır.

Bilişim terimlerinin Türkçeleştirilmesinde kişisel çabaların da büyük katkısı olmuştur. Bu alanda Aydın Köksal'ın çok önemli bir yeri vardır; zira günlük dile de girmiş olana bilgisayar, yazıcı, donanım, yazılım gibi pek çok bilişim terimlerini ona borçluyuz.

Genel ağda yayımlanan sözlük, liste ve kılavuzlar bir kenara bırakılırsa bugüne kadar otuzun üzerinde bilişim/bilgisayar terimleri sözlüğü ve karşılıklar kılavuzunun yayımlandığı görülür. Bunların içerisinde Türk Dil Kurumu tarafından yayımlanan Bilişim Terimleri Sözlüğü ile Bilgisayar Terimleri Karşılıklar Kılavuzu adlı eserler hem terimlerin geleneksel imlasını koruması hem de farklı sözcüklerle karşılanan kavramların kullanıcılar tarafından çokça tercih edilen şekillerini bünyesinde barındırması sebebiyle oldukça önemlidir.

Türkçe bilişim terimlerinin oluşum süreçlerini tespit etmeyi hedefleyen bu çalışmada Türk Dil Kurumu tarafından 2013'te yayımlanmış olan Bilgisayar Terimleri Karşllkklar Kılavuzu adlı eserdeki terimler esas alınmıştır. İki ayrı bölümden oluşan Kılavuz’un Türkçe-İngilizce dizininde 4801 terim, İngilizceTürkçe dizininde ise 4604 terim yer almaktadır. Aradaki farkın sebebi ise bazı terimlere birden çok karşıllk verilmesidir. Tekrarlar ve çapraz gönderimler sebebiyle çalışmamızda 4366 terim incelenmiştir. Söz konusu terimler, oluşum süreçleri göz önünde bulundurularak sinıflandırılmıştır. Türkçe bilişim terimleri oluşturulurken on bir farklı yöntemin kullanıldı̆̆ı görülmüştür:

1. Anlam aktarması (calque),

2. Kopyalama (copying),

3. Başharfleştirme (initialism),

4. Türetme (derivation),

5. Genel dilden sözcük aktarma,

\footnotetext{
Adres Address

İstanbul Medeniyet Üniversitesi, Eğitim Bilimleri Fakültesi, Türkçe İstanbul Medeniyet University, Faculty of Education Sciences, ve Sosyal Bilimler Eğitimi Bölümü, Türkce Eğitimi ABD Cevizli Turkish and Social Scinces Education, Turkish Language Teaching Kampüsü, Kartal-İstanbul/TÜRKIYE $\quad$ Education, Cevizli Campus, Kartal-İstanbul /TURKEY e-posta: editor@rumelide.com 1 e-mail: editor@rumelide.com
} 

6. Birleştirme (compounding),
7. Geri oluşum (backformation),
8. Ağızlardan sözcük aktarma,
9. Karma (blending),
10. Ana dilden örnekseme (analogy),
11. Genelleşme (generalization),

Dilin pek çok alanında olduğu gibi terim üretiminde de diller arası ilişkilerin çok önemli bir rolü vardır. Dil ilişkilerinin en yoğun olarak hissedildiği alanların başında söz varlığı gelmektedir. Ortaya çıkan ve adlandırılmayı gerektiren her durum için bir göstergenin bulunması gerekmektedir. $\mathrm{Bu}$ durum yabancı dillerden sözlüksel unsurları kopyalamayı veya dil içi yöntemlerle yeni sözcükler üretmeyi zorunlu kılmaktadır. Diğer taraftan dilde özleşme arayışları da farklı dillerden kopyalanmış unsurlara yerli kaynaklarla karşılıklar üretme çabalarını artırmaktadır (Sarı, 2013: 12). Bilindiği gibi her terim oluştuğu dil ve kültürden izler taşır. Bilişimle ilgili buluşların çok önemli bölümünün Avrupa ve Kuzey Amerika'da ortaya çıması bu alandaki terminolojinin İngilizce sözcüklerle oluşmasına sebep olmuştur. Farklı dilleri konuşan milletler bu terimleri ya olduğu gibi kopyalamış ya da onlara kendi dillerinden karşıllklar üretme yoluna gitmiştir. Ülkemizde de 1960'lı ylllardan itibaren söz konusu terimlere Türkçe karşlıklar bulma arayışları başlamıştır. Bu arayışların neticesi olarak ortaya çıkan Bilgisayar Terimleri Karşıllklar Kılavuzu'ndan hareketle Türkçe bilişim terimlerinin oluşum şekilleri ve yüzdelik dağılımları şu şekilde sıralanmıştır:

Tablo 1. Türkçe bilişim terimlerinin oluşum şekilleri

\begin{tabular}{|c|c|c|c|c|}
\hline & $\begin{array}{l}\text { Terim } \\
\text { oluşturma } \\
\text { yöntemi }\end{array}$ & Terim adedi & Yüzdelik payı & Örnek \\
\hline 1 & $\begin{array}{l}\text { Anlam aktarması } \\
\text { yoluyla } \\
\text { oluşturulmuş } \\
\text { terimler }\end{array}$ & 3433 & 78,6 & $\begin{array}{l}\text { Tü. hesaplamak } \\
\text { İng. calculate }\end{array}$ \\
\hline 2 & $\begin{array}{l}\text { Hem anlam } \\
\text { aktarması hem de } \\
\text { kopyalama yoluyla } \\
\text { oluşturulmuş } \\
\text { terimler }\end{array}$ & 382 & 8,7 & $\begin{array}{l}\text { Tü. uygulama } \\
\text { programı } \\
\text { İng. application } \\
\text { program }\end{array}$ \\
\hline 3 & $\begin{array}{l}\text { Hem anlam } \\
\text { aktarması hem de } \\
\text { genel dilden } \\
\text { sözcük aktarma } \\
\text { yoluyla } \\
\text { oluşturulmuş } \\
\text { terimler }\end{array}$ & 173 & 3,9 & $\begin{array}{l}\text { Tü. veri akış hızı } \\
\text { birimi } \\
\text { İng. baud rate }\end{array}$ \\
\hline 4 & $\begin{array}{l}\text { Kopyalama yoluyla } \\
\text { oluşturulmuş } \\
\text { terimler }\end{array}$ & 84 & 1,9 & $\begin{array}{l}\text { Tü. bit } \\
\text { İng. bit }\end{array}$ \\
\hline 5 & $\begin{array}{l}\text { Genel dilden } \\
\text { sözcük aktarma } \\
\text { yoluyla } \\
\text { oluşturulmuş }\end{array}$ & 67 & 1,5 & $\begin{array}{l}\text { Tü. kâğıt ayırıcı } \\
\text { İng. burster }\end{array}$ \\
\hline
\end{tabular}


terimler

Hem anlam

aktarması hem de

Tü. Önbellek tamponu

İng. cache buffer

Hem anlam

aktarması hem de

başharfleştirme

yoluyla

lusturulmus

terimler

Hem anlam

aktarması hem de

türetme yoluyla

oluşturulmuş

terimler

Türetme yoluyla

olușturulmuş

22

terimler

Hem kopyalama

hem de genel

dilden sözcük

aktarma yoluyla

usturulmus

terimler

Birleştirme yoluyla

olusturulmus

terimler

14

Hem türetme yoluyla hem de genel dilden

sözcük aktarma

yoluyla

olușturulmus

terimler

Hem kopyalama

hem anlam

aktarması hem de

genel dilden

sözcük aktarma

7

yoluyla

oluşturulmuş

terimler

Hem kopyalama

hem de birleştirme

yoluyla

5

oluşturulmuş

terimler

Hem kopyalama hem anlam
4
0,16

0,16

0,11

0,091
Tü. DA

bağdaştırıcısı

İng. $\mathrm{AC}$ adapter

Tü. giden ileti

İng. outgoing

message

Tü. bilișim

İng. informatics

Tü.

bilgilendirilecekler

listesi

İng. carbon copy list

Tü. ikileşlemli

Ing. bitmap

Tü. büyük küçük harf ayırsamalı

İng. match case

Tü. appletalk dosya iletişim kuralı İng. appletalk file protocol

Tü. analog bilgisayar

İng. analog

computer

Tü. Plx EDV test

kartı sürücüsü 
aktarması hem de

başharfleştirme

yoluyla

oluşturulmuş

terimler

Hem genel dilden

sözcük aktarma

hem de

başharfleştirme

yoluyla

3

oluşturulmuş

terimler

Hem anlam

aktarması hem de

karma yoluyla

oluşturulmuş

terimler

Ağızlardan sözcük

aktarma yoluyla

oluşturulmuş

3

3

0,068

terimler

Hem anlam

aktarması hem de

19 genelleşme yoluyla oluşturulmuş terimler

2

Hem kopyalama hem de türetme

yoluyla

olușturulmuş

terimler

Hem türetme hem anlam aktarması

21 hem de kopyalama yoluyla oluşturulmuş terimler

Karma yoluyla oluşturulmuş terimler

Hem anlam aktarması hem genel dilden sözcük aktarma

hem de

başharfleştirme

yoluyla oluşturulmuş terimler

Geri olușum terimler
İng. Plx USB test

board driver

Tü. İKD yardımcı programları

İng. TCP utilities

Tü. belgeç sunucusu

İng. facsimile server

Tü. kiplemek

İng. modulate

Tü. Machintosh

adları

İng. Machintosh

names

Tü. Boleo işleci

İng. Boleo operator

Tü. işlemci sunucu modeli

İng. client-server model

Tü. belgeç

İng. facsimile

Tü. EDV kişisel

birim

İng. USB personality module

Tü. bankamatik

İng. outomated teller machine 
Hem birleştirme

hem de

başharfleştirme

yoluyla

0,022

oluşturulmuş

terimler

Hem anlam

aktarması hem de

terimler

\section{Hem}

başharfleștirme

hem anlam

oluşturulmuş

terimler

Hem genel dilden

sözcük aktarma

oluşturulmuş

terimler

\section{Hem}

başharfleştirme

hem de kopyalama

yoluyla

oluşturulmuş

terimler

Ana dilden

örnekseme yoluyla

oluşturulmuş

terimler

Hem türetme hem

de kopyalama

oluşturulmus

terimler

Tü. AAS sunucusu adresi

İng. DNS server adress

Tü. programlanır uçbirim

İng. intelligente terminal

\section{Hem anlam}

aktarması hem

birlestirme hem de

yoluyla

olușturulmus

terimler

Hem türetme hem

anlam aktarması

hem de genel
Tü. SGK paneli

İng. LCD panel

Tü. dönüt

İng. feedback

Tü. birimsel programlama İng. modular programming

Tü. YBB takmalı ana İng. PCI-docking host bridge

Tü. eşlikli çubuklu disk birimi kümesi Ing. stripe set with parity sistem köprüsü aktarma yoluyla oluşturulmuş terimler 
Hem kopyalama

hem anlam

34 aktarması hem de

birleştirme yoluyla

oluşturulmuş

terimler
Tü. telnet uçbirim

kimliği

İng. telnet terminal

ID

Yeni nesne, durum, olgu ve uygulamalar adlandırılırken, çoğu zaman, yeni anlam birimlerin ortaya çıkmadığı görülür. Bu gibi durumlarda daha ziyade dilde hâlen kullanımda olan anlam birimlere yeni görevler yüklenir veya birkaç anlam birim bir araya getirilerek ihtiyacın karşılanması yoluna gidilir (Martinet, 1998: 198). İngilizceden Türkçeye yapılan terim aktarmalarında, kullanımda olan anlam birimlerle açılama yolunun benimsendiği görülmüştür (Eriş ve Uluşahin, 2020: 817). Bilişim terimleri Türkçeleştirilirken de çoklukla dilde varlığını sürdüren anlam birimlerin (kapatmak, sürücü vb.) kullanıldığı ve sınırlı sayıda yeni anlam birimin (bilköşk, bilişim vb.) ortaya çıtığı tespit edilmiştir. $\mathrm{Bu}$ durumun temel sebebi terimlerin çoğunlukla anlam aktarması yöntemiyle oluşturulmasıdır.

\section{Sonuç}

Türkçe terim yapma yolları ve bilişim terimlerinin oluşum süreçlerini ortaya koymayı amaçlayan bu çalışmada şu sonuçlara ulaşılmıştır:

1. Terimler, hem oluşum hem de kullanım alanlarındaki farklılıklar sebebiyle günlük dildeki sözlük birimlerinden ayrılır. Bu çalışmada terimleri diğer sözlük birimlerden ayıran on bir özellik tespit edilmiştir.

2. Ülkemizde terimler üzerine pek çok çalışma yapılmış olsa da bunların küçük bir kısmı terim yapma yollarıyla ilgilidir. Söz konusu çalışmalardan hareketle Türkçede yirmi adet terim yapma yolunun bulunduğu tespit edilmiştir.

3. 1960'ların başından itibaren, çoğunlukla İngilizceden dilimize girmeye başlayan bilişim terimleri 1964'ten sonra Türkçeleştirilmeye çalışılmıştır. Bu amaca yönelik ilk önemli çalışma Kara Kuvvetleri Komutanlığı bünyesinde Dr. Müh. Tğm. Okan Gürel ve Y. Müh. Tğm. Olcay Göksu tarafından hazırlanan “Otomatik Bilgi İşlem Terimleri” adlı sözlüktür. Bu çalışmadan sonra otuz civarında bilişim ve bilgisayar terimleri sözlüğü yayımlanmıştır.

4. Bilişim terimlerinin çok önemli bir kısmı sadece bir terim yapma yöntemi kullanılarak, nispeten daha küçük bir kısmı ise birkaç yöntemin bir arada kullanılmasıyla oluşturulmuştur. Söz konusu terimlerin \%83'ü (3627) yalnızca bir terim yapma yöntemiyle oluşturulurken, \%16'sı (719) iki ve \%o,5’i (17) üç farklı terim yapma yönteminin bir arada kullanılmasıyla vücuda getirilmiştir. Ayrıca Türkçe bilişim terimlerinin oluşum sürecinde temelde on bir farklı yöntem ve bu yöntemlerin otuz dört değişik kombinasyonu kullanılmıştır.

5. Bilişim terimlerinin Türkçeleştirilmesi sürecinde en sık kullanılan yöntem anlam aktarmasıdır. Terimlerin \%78'i sadece anlam aktarması yöntemiyle oluşturulmuş, \%15'inde ise ikinci veya üçüncü terim oluşturma yöntemi olarak anlam aktarması kullanılmıştır. Kısacası bilişim terimlerinin \%93'ünde ana veya tali terim oluşturma yöntemi olarak anlam aktarması kullanılmıştır.

6. Verilerden de anlaşılacağı üzere 1950'li yıllardan itibaren dilimize girmeye başlayan bilişim terimleri Türkçeye aktarılırken daha çok, dilde var olan anlam birimlerinden yararlanılmış, pek az yeni anlam birim ortaya çıkabilmiştir. Bu alanda sınırlı sayıda yeni sözcüğün oluşmasının temel sebebi terimlerin büyük bir bölümünün dilin doğal üretim sürecinde ortaya çıkmaması yani önceden başka bir dilde adlandırılmış olan nesne, durum, olgu veya uygulamaların Türkçeye anlam aktarması yoluyla tercüme edilmesidir.

Adres

İstanbul Medeniyet Üniversitesi, Eğitim Bilimleri Fakültesi, Türkce ve Sosyal Bilimler Eğitimi Bölümü, Türkce Eğitimi ABD Cevizli Kampüsü, Kartal-İstanbul/TÜRKIYYE e-posta: editor@rumelide.com
Address

Istanbul Medeniyet University, Faculty of Education Sciences,

Turkish and Social Scinces Education, Turkish Language Teaching

Education, Cevizli Campus, Kartal-İstanbul /TURKEY

e-mail: editor@rumelide.com 


\section{Kaynakça}

Ahanov, K. (2013). Dil Bilimin Esasları. Ankara: TDK.

Aksan, D. (2007). Her Yönüyle Dil Ana çizgileriyle Dilbilim. c. 3, Ankara: TDK.

Akalın, H. Ş., vd. (2013). Bilgisayar Terimleri Karşılıklar Kılavuzu. Ankara: TDK.

Arifoğlu, A., vd. (1996). Bilişim Terimleri Sözlüğü. Ankara: TBD.

Aydın, E. D. (1982). Bilişim Nedir. İstanbul: MISTAŞ̧.

Aydoğdu, Ş.,vd. (2017) Bilgisayara Giriş (ed. Gökçe Becit İşçitürk). Ankara: Pegem.

Buran, A. (2006). Dil İlişkileri ve Kavram Tercümeleri Üzerine Bir Değerlendirme. 12. Uluslararası KIBATEK Edebiyat Şöleni, Bakü/Azerbaycan: 10-17 Mayıs: s. 1-4.

Campbell-Kelly, M., vd. (2014). Computer: A History of the Information Machine. New York: Westview Press.

Çimen, A. (2014). Tarihi Değiştiren İcatlar ve Mucitler. İstanbul: Timaş.

Demirci, K. (2017). Türkoloji İçin Dilbilim. Ankara: Anı.

Dilaçar, A. (1957). Terim nedir? Türk Dili, C. 4, S. 64, s. 207-210.

Eker, S. (2003). Çağdaş Türk Dili. Ankara: Grafiker.

Eker, S. (2013). Modernleşme Sürecinde Türkiye'de Terimbilim Çalş̧malarına Genel Bir Bakış. Astana: Turkıc Akademi (Altaistics and Turkology). I.

Eriş, E., Uluşahin, E. (2020). Technical and Economic Terms Translation Based on Metaphors. RumeliDE Dil ve Edebiyat Araşttrmaları Dergisi, (19), 803-812. DOI: 10.29000/rumelide. 752823 .

Ellyard, D. (2017). Kim Neyi Ne Zaman İcat Etti (Çev. Uğur Mutlu). Ankara: TÜBİTAK.

Günay, D. (2007). Sözcükbilime Giriş. İstanbul: Multilingual.

Haugen, E. (1950). The Analysis of Linguistic Borrowing. Language, 26, 210-231.

IBM 1620 fortran II spesifikasyonları (1964). (Çev. Şenol Utku). İstanbul: İTÜ Hesap Merkezi: 1.

İhsanoğlu, E. (1985). Osmanlı Devleti’ne XIX. yy.da Bilimin Girişi ve Bilim-Din İlişkisi Hakkında Bir Değerlendirme Denemesi. Toplum ve Bilim, S. 29-30, s. 79-102.

Kahraman, M. (2017). Türk Dilinin Cumhuriyet Devri Terimsel Gelişim Sürecine Tarihî Bakış (II). İnsan ve Toplum Bilimleri Araştırmaları Dergisi, C. 6, S. 2, s. 1298-1312.

Kara, İ. (2016). Bir Felsefe Dili Kurmak Modern Felsefe ve Bilim Terimlerinin Türkiye'ye Girişi. İstanbul: Dergah.

Karaman, B. İ. (2009) Terim Oluşturma Yöntemleri. TDK Belleten, 2009-II.

Karaman, B. İ. (2017) Terimbilimi. İstanbul: Bilgesu.

Köksal, A. (1978). Bilişim Terimleri ve Öneriler Kılavuzu. Ankara: TBD.

Köksal, A. (1981). Bilişim Terimleri Sözlüğü. Ankara: TDK.

Köksal, A. (1983). Elli Yıl Boyunca Türk Dil Kurumu Terim Kolu Çalışmaları. Türk Dili, S. 381, s. 269278.

Levend, A. S. (2010). Türk Dilinde Gelişme ve Sadeleşme Evreleri. Ankara: Dil Derneği.

Martinet, A. (1998). İşlevsel Genel Dilbilim. (Çev. Berke Vardar). İstanbul: Multilingual.

Gürel, O., Göksu, O. (1964). Otomatik Bilgi İşlem Terimleri. Ankara: KKK Elektronik Hesap Merkezi: 2.

Özdemir, E. (1973). Terim Hazırlama Kılavuzu. Ankara: TDK.

\footnotetext{
Adres $\mid$ Address

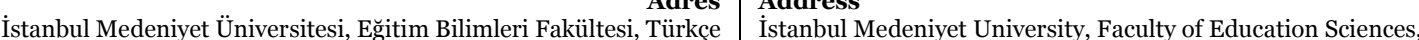
ve Sosyal Bilimler Eğitimi Bölümü, Türkce Eğitimi ABD Cevizli Turkish and Social Scinces Education, Turkish Language Teaching Kampüsü, Kartal-İstanbul/TÜRKIYE Education, Cevizli Campus, Kartal-İstanbul /TURKEY e-posta: editor@rumelide.com 1 e-mail: editor@rumelide.com
} 
Özdemir, E. (1980). Dil Devrimimiz. Ankara: TDK.

Özdem, R. H. (1941). Terim Meselesi Münasebetiyle Dilimizin Islahı Üzerinde Bir Muhtıra. İstanbul: İ.Ü..

Özdem, R. H. (2000). Terimler Hakkında. Dilbilim Yazıları (Haz. Recep Toparlı). Ankara: TDK.

Özkan, A. (2015). Anı ve Fotoğraflarla Bilişim Tarihimiz. İstanbul: TÜBİSAD.

Özön, M. N. (1972). Terim Kılavuzu. İstanbul: Maarif Matbaası.

Palferman, J., Swade, D. (1993). The Dream Machine : Exploring the Computer Age. London: BBC Books.

Sağlam, M. Y. (2006). Türkçedeki Terim Sorunsalı. Türkbilig, S. 14, s. 168-176.

Sarı, İ. (2013). Dil Etkileşimi Bağlamında Ses-Anlam Eşlemesi ve Türkçedeki Örnekleri. Türk Kültürü, Ankara: Türk Kültürünü Araştırma Enstitüsü, 1-27.

Sarıtosun, N. (1992). Terim Hazırlama Kılavuzu. İstanbul: İ.T.Ü.

Şahin, H. (2006). Terimlerin Genel Dile Yansımasına Dair Bazı Gözlemler. Sosyal Bilimler Enstitüsü Dergisi, Bursa, 2006 / 1, s. 123-129.

Tameroğlu, S. S. (2001). Bilimlerin Tarihi. İstanbul: Birsen.

Tariktaroğlu, A. (1998). Türk Dilinde Terimler. Türk Dili, S. 559, s. 74-80.

Taşçı, C.N., Mutlu, M.E. (1991). Bilgisayar Tarihi. İstanbul: Alternatif Üniversite.

Uysal, H. (2013). Yabancı Terimleri Türkçeleştirmede Uygulanan Yöntem ve İlkeler (1932-1950 arası). (Yayımlanmamış Yüksek Lisans Tezi) Ankara, Ankara Üniversitesi S.B.E.

Vardar, B. (1980). Terimsel Etkinlik ve Terimbilim. Türk Dili, Ankara: Türk Dili, (XLI/46), s. 385-389.

Vardar, B., vd. (2002). Açıklamalı Dilbilim Terimleri Sözlüğü. İstanbul: ABC.

Vinay, J.P., Darbelnet, J. (1995). Comparative Stylistics of French and English: A Methodology for Translation. Joh Benjamins Publishing.

Zülfikar, H. (1991). Terim Sorunları ve Terim Yapma Yolları. Ankara: TDK.

75. Yılında Devlet İstatistik Enstitüsü: 1926-2001. (2001). Ankara: DİE.

http://www.columbia.edu/cu/computinghistory/hollerith.html (o9/02/2020)

https://encyclopedia.ushmm.org/content/tr/article/world-war-ii-key-dates (10/02/2020)

https://history-computer.com/ModernComputer/Relays/Zuse.html (09/02/2020)

https://sozluk.gov.tr/ (05/02/2020)

\footnotetext{
Adres $\mid$ Address

İstanbul Medeniyet Üniversitesi, Eğitim Bilimleri Fakültesi, Türkçe İstanbul Medeniyet University, Faculty of Education Sciences,

ve Sosyal Bilimler Eğitimi Bölümü, Türkce Eğitimi ABD Cevizli Turkish and Social Scinces Education, Turkish Language Teaching

Kampüsü, Kartal-İstanbul/TÜRKIYE $\quad$ Education, Cevizli Campus, Kartal-İstanbul /TURKEY

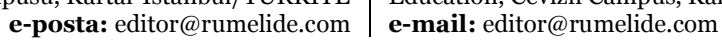

